\title{
Are Budget and Current Account Deficits Twins in Turkey? Evidence from Residual-based Fourier Cointegration and Fourier Causality Analyses'
}

Mustafa Erhan BILLMAN (https://orcid.org/0000-0003-4058-8681), Department of Economics, İzmir Kâtip Çelebi University, Turkey; e-mail: merhan.bilman@ikcu.edu.tr

\section{Türkiye'de Bütçe ve Cari İşlemler Açıkları İkiz Mi? Kalıntı Temelli Fourier Eşbütünleşme ve Fourier Nedensellik Analizlerinden Kanıtlar²}

\begin{abstract}
This paper explores the relationship between the Turkish fiscal and current account balances with quarterly data spanning through 2006:1-2020:2 and adopting residual-based Fourier cointegration (or Fourier Engle-Granger, FEG) and Fourier Granger causality approaches. The findings from the FEG estimations suggest that budget and current account balances are cointegrated under smooth breaks in the series. More specifically, an improvement in the fiscal balance leads also to an amelioration in the current account balance - an outcome in line with the twin deficit hypothesis. In addition, a Fourier Granger causality analysis is performed for robustness check purposes. The findings are consistent with those from the FEG tests, which imply that a one-way causality running from the fiscal to the external balance is proved to be the case under smooth structural changes.
\end{abstract}

Keywords $\quad$ : Twin Deficit Hypothesis, Residual-Based Fourier Cointegration, Fourier Granger Causality.

JEL Classification Codes : C22, E62, F41, H62.

\section{$\ddot{\mathbf{O z}}$}

Bu çalışma, Türkiye'nin bütçe dengesi ile cari işlemler dengesi arasındaki ilişkiyi, 2006:12020:2 dönemine ilişkin üç aylık verileri kullanarak ve kalıntı temelli Fourier eşbütünleşme (ya da Fourier Engle-Granger, FEG) ve Fourier Granger nedensellik yaklaşımlarını benimseyerek keşfetmektedir. FEG tahminlerinden elde edilen sonuçlar, bütçe ve cari işlemler dengesinin serilerdeki yumuşak yapısal kırılmalar altında eşbütünleşik olduğunu göstermektedir. Daha açık bir anlatımla; mali dengedeki bir iyileşme, cari işlemler dengesinde de bir düzelmeye neden olmaktadır ki; bu bulgu, ikiz açık hipotezinin geçerliliğini desteklemektedir. Sağlamlık (robustness) sınaması amacı güdülerek, bir Fourier Granger nedensellik analizi de yürütülmüştür. Ondan elde edilen bulgular ile FEG testinden

1 This article is produced from the author's master's thesis titled "The Twin Deficits Phenomenon: Evidence from Turkey" (dissertation number: 145368). The empirical analyses of the original thesis, which was accepted unanimously in 2004, are enhanced in this paper by adopting the most recent developments in cointegration and causality procedures and employing the most up-to-date data set. For this reason, the empirical findings of this study are different from those of the original thesis.

2 Bu makale, yazarın "İkiz Açık Olgusu ve Türkiye Açısından Değerlendirilmesi" başlıkl yüksek lisans tezinden (yayın no: 145368) türetilmiştir. 2004 yılında oybirliği ile kabul edilen ilgili yüksek lisans tezinin ampirik analizleri bu çalı̧̧mada, eşbütünleşme ve nedensellik yöntemlerindeki en yeni gelişmeler benimsenerek ve en güncel veri seti kullanılarak yeniden yapılmıştır. Bu nedenle, bu çalışmanın ampirik bulguları orijinal tezdekilerle farklllık göstermektedir. 
elde edilenler tutarlıdır, şöyle ki; mali dengeden cari işlemler dengesine doğru tek yönlü bir nedensellik ilişkisinin varlığı, yumuşak yapısal değişimler altında tespit edilmiştir.

\begin{abstract}
Anahtar Sözcükler I İkiz Açık Hipotezi, Kalıntı Temelli Fourier Eşbütünleşme, Fourier Granger Nedensellik.
\end{abstract}

\title{
1. Introduction
}

\subsection{Theoretical Framework}

The academics and even the layperson in the US were reckoning that the policy makers of the Reagan government in the early 1980s might be blamed for the skyrocketing current account or trade deficits due to the administration's generous expenditures which led to record federal budget deficits. As noted by Feldstein (1992), these two deficits were then regarded as "Siamese twins" in the US, which are impossible to be separated from each other. The leading studies investigating the twin deficit hypothesis (TDH, henceforth) generally deal with the US data, since the core of the debate was the US' chronic budget deficits which may be the reason behind the worsening current account or trade balance (see, McKinnon, 1980; Laney, 1984; Summers, 1986; Gordon, 1986; Miller \& Russek, 1989; McKinnon, 1990; Abell, 1990, among others). These studies mostly report strong empirical support for the existence of the twin deficits.

Twin deficits are associated with each other depending on two linkages. The first link considers the Mundell-Fleming model which presumes perfect capital mobility under flexible exchange rate regime. In this framework, a rise in fiscal deficits due to increased expenditures generates an increase in domestic interest rates which triggers an inflow of capital which would appreciate the domestic currency. The appreciated domestic currency encourages imports and deters exports, which in turn deteriorates the current account or trade balance. These developments will be the case under the fixed exchange rate system as well, because the fiscal incentive under a fixed rate system would increase domestic real income which successively deteriorates the external balance (see, Salvatore, 2006; Anoruo \& Ramchander, 1998). The latter connection is put by the Keynesian absorption framework. It postulates that an increase in fiscal expenditures stimulates domestic absorption and imports, a development that gives rise to a worsening current or trade account.

Another theoretical contribution closely related to the twin deficits literature is made by Feldstein and Horioka (1980). Their findings suggest that there is a strong correlation between the national savings and domestic investments in the OECD countries. This finding was interpreted by Feldstein and Horioka (1980), Feldstein (1983), and Feldstein and Bacchetta (1989) as an evidence for the existence of low degree of long-term capital mobility at the international level. The finding that a co-movement exists between national savings and domestic investments was met by harsh criticism, because it contradicts the expected impacts of enhanced deregulations as well as integration accomplished until that time in the global financial markets (see Tobin, 1983; Murphy, 1984; Obstfeld, 1986; Frankel \& 
MacArthur, 1988; Frankel, 1991; Baxter \& Crucini, 1993; and more recently Levy, 2000). The "Feldstein-Horioka puzzle", which is also referred to as "the mother of all puzzles" by Obstfeld and Rogoff (2000), entails that the twin deficits would not coexist due to low degree of capital mobility. However, Helliwell (1990) noted that TDH may hold true as long as the causality running from national savings to domestic investments is accounted for by interest rates. In that case, an increased budget deficit may bring about a worsening external balance, contingent on the condition that the escalated interest rates stimulate the overvaluation of the domestic currency.

Barro $(1974 ; 1989)$, puts forward that an increase in the budget deficits would leave the current account or trade balance unscathed on the grounds that the agents are wise enough to predict that a tax reduction made by the government today would bring extra taxes levied on the consumers tomorrow. For this reason, the consumers do not take the tax cut, namely the increase in their real income seriously and thus they do not increase their imports, but they save instead to meet the future taxes. Those farsighted agents lead to the disappearance of the connection between the budget and the current account balance. This theoretical justification is known as the Ricardian equivalence hypothesis (REH, henceforth).

More recently, Kim and Roubini (2008) discovered a paradoxical aspect of the US current account and fiscal balance data. They proved that the relationship between the US' fiscal and current account deficits is not uniform between 1980 and 2004. Instead of a comovement, a divergence between the twins, i.e. the twin divergence hypothesis (TDiH), may also be the case when the main driver of the two deficits is an output shock. To put it more precisely, the budget balance is pro-cyclical whereas the current account balance is countercyclical in the face of an output or a productivity shock. Kim and Roubini (2008) note also that even the exogenous fiscal deficit shocks generate an improvement in the current account, an outcome verifying the unusual TDiH.

Summers (1988) is another pioneering paper that found a converse causality running from the current account deficit to the fiscal imbalance, which is referred to as the current account targeting hypothesis (CATH). This correlation depends on the idea that a slower economic performance is brought about by enlarging current account deficits, which also generates a deteriorated fiscal balance by lowering tax revenues and increasing government expenditures.

\subsection{Review of the Empirical Literature}

As noted above the leading studies mostly report supportive empirical evidence for the existence of the traditional TDH (see, Summers, 1986; Darrat, 1988; Abell, 1990; Zietiz \& Pemberton, 1990; Bachman, 1992; Kasa, 1994; Vamvoukas, 1999; Normandin, 1999; Piersanti, 2000; Cavallo, 2005; and Salvatore, 2006, among others). On the contrary, there are numerous studies that demonstrate the validity of a disconnection between the two deficits, i.e. the REH, for different countries and/or country groups by employing time series 
or panel data methodologies (see Miller \& Russek, 1989; Andersen, 1990; Dewald \& Ulan, 1990; Enders \& Lee, 1990; Kim, 1995; Kaufmann, Scharler, Winckler, 2002; and Algieri, 2013, among others). Besides, Kim and Roubini (2008) illustrated an unusual relationship that characterizes the US data, the TDiH. Similarly, Ahmad, Aworinde and Martin (2015) found evidence in favor of the TDiH, along with the TDH, for selected African economies. As mentioned previously, there also exist empirical studies which report a reverse relationship where the current account deficit is the cause and the fiscal deficit is the result, i.e. the CATH (see, Summers, 1988; Anoruo \& Ramchander, 1998; Khalid \& Guan, 1999; Kim \& Kim, 2006; Marinheiro, 2008; and Stiglitz, 2010).

\subsection{Significance of the Research Question in terms of Turkey}

Turkey, beyond doubt, has shown a great deal of progress in fulfilling liberalization both in finance and trade following the 1980s, which in turn added to its openness at the international level. As a small "more open" economy, Turkey takes full advantage of the merits, but at the same time faces the snares associated with its integration into the global markets. In addition to being open, Turkey is considered also a developing nation. Financial liberalization enabled Turkey to reach to the international funds easily to finance its economic growth and development, while making it more prone to negative shocks which result from the cross-country spillovers of economic crises. For instance, despite the fact that the recent global financial crisis which broke out in 2008 did not hit Turkey hard, a sharp deterioration in the fiscal balance between 2008:3 and 2011:2 is conspicuous in Figure 1 below. A similar pattern is the case also for the external balance, since it suffers from deficits following the crisis, namely between 2010:1 and 2012:2. Taking the picture depicted in Figure 1 into consideration, one may think that the steep rises in both budget and current account deficits will probably get even worse following 2020:2 due to a relentlessly devastating global economic crisis triggered by the Covid-19 pandemic. The tendency of the fiscal discipline to disappear during bad times can be ascribed to the government's role in stimulating the economic activity by extra expenditures combined with falling tax revenues due to the economic downturn. And the justification for the deterioration in the current account balance may well be the dwindling international demand.

However, Turkey's inveterate budget and external imbalances cannot be explained solely by global factors. Turkey's own peculiar reasons also fuel the budget deficits-the ongoing need to spend on infrastructure; general and local elections held frequently; and importantly, the deep-seated generous fiscal policy praxis to name a few. As for the flip side of the coin, the ever-rising necessity to import energy, raw materials, and intermediate products; sluggish exports; and noticeably skittish exchange rates can be counted among the typical reasons behind the Turkish current account imbalances. It stands to reason therefore, that the potential theoretical connections between the deficit duo of Turkey should be investigated via formal testing methodologies so as to propose the most appropriate policy steps. 


\subsection{Motivation and Novelty of the Study}

The apparent inconclusiveness in the literature is attributed to the lack of nonlinearities in the empirical procedures adopted thus far. This criticism is put forward by Bagnai (2006) and supported by Daly and Siddiki (2009); Rafiq (2010); Holmes (2011); Trachanas and Katrakilidis (2013); Ahmad, Aworinde and Martin (2015); and most recently by Bilman and Karaoğlan (2020). Following these contributions, this paper postulates also that the relationship between the fiscal and current account balance can best be modelled by a nonlinear perspective which takes into account the structural breaks that represent the true behavior of macroeconomic data. For this reason, this study explores the association between Turkish fiscal and current account balance by employing residual-based Fourier cointegration and Fourier Granger causality methods, initially introduced by Yllanc1 (2019), and Enders and Jones (2016), respectively. The empirical techniques conducted in this study are superior to those with linear settings as they consider structural breaks of indefinite number and form, a specification which enables them to better portray the actual relationships between macroeconomic series such as those employed here. As far as the author of this study is concerned, there appears to be no prior paper that follows cointegration and causality analyses which rely on Fourier series approximation in the investigation of the TDH.

In other words, novelty of the findings from this article can be accredited to the empirical methodologies adopted. Fourier-type cointegration and causality tests serve as a robustness check for the parameter estimates since they allow for a comparison between the findings from two distinct yet mathematically and statistically consistent time series procedures. Furthermore, I also applied the linear (conventional) causality test along with its nonlinear (Fourier-type) counterpart to prove that the nonlinear approach has a better specification which can capture the true causality between the fiscal and external balances of Turkey under smooth structural breaks, an exercise that acts as a further robustness testing. The rest of the study is organized as follows: Second section presents the data and the empirical procedures. Third section shows and interprets the empirical findings and finally, the fourth section concludes and puts economic policy suggestions.

\section{Data and the Empirical Methodology}

\subsection{Data}

This paper investigates the relationship between the government budget balance (BB) and the current account balance (CA) of Turkey by using quarterly data covering the period 2006:1 and 2020:2 and employing residual-based Fourier cointegration and Fourier Granger causality tests. CA and BB series are gathered from the online database of the Central Bank of the Republic of Turkey (EVDS). CA and BB series are calculated respectively as the current account balance and the budget balance divided by the GDP. Budget balance is taken as the revenues minus expenditures, meaning that an increase in BB series represents an improvement in the government budget. Similarly, a rise in CA series implies the 
amelioration of external balance. Descriptive statistics and the time plots for individual series are presented in Table 1 and Figure 1, respectively.

Table: 1

\section{Descriptive Statistics for CA and BB Series}

\begin{tabular}{|c|c|c|}
\hline & $C A$ & $B B$ \\
\hline Mean & 0.005577 & -0.020389 \\
\hline Median & 0.002469 & -0.019387 \\
\hline Maximum & 0.087732 & 0.029853 \\
\hline Minimum & -0.054251 & -0.095461 \\
\hline Std. Dev. & 0.029034 & 0.022499 \\
\hline Skewness & 0.930951 & -0.624804 \\
\hline Kurtosis & 4.121209 & 4.454534 \\
\hline Observations & 58 & 58 \\
\hline
\end{tabular}

Source: Computed by the author.

Figure: 1

Time Plots for CA and BB Series

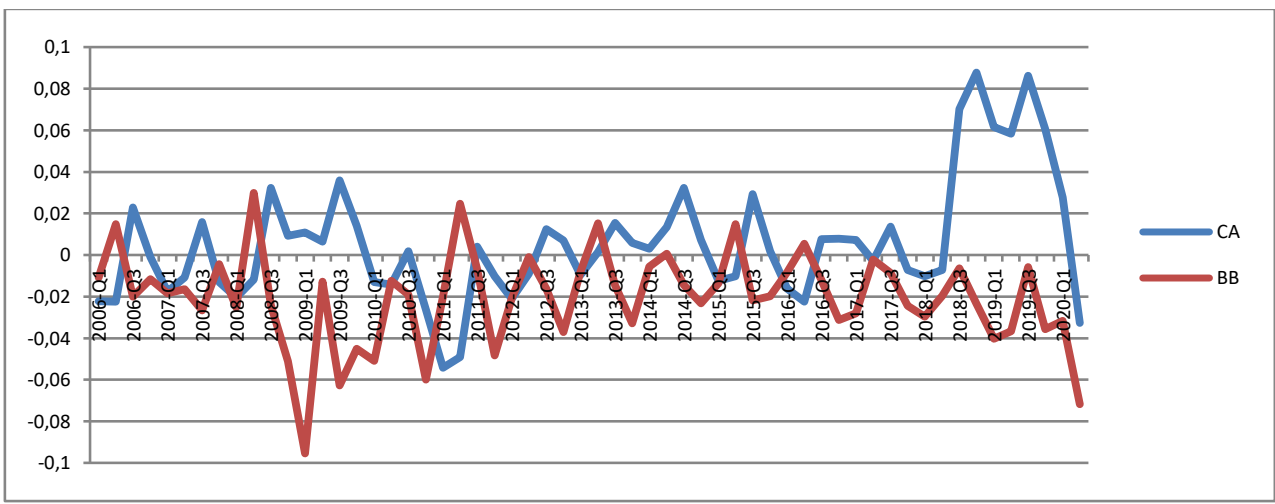

Source: Produced by the author.

What is prominent in Figure 1 is that the BB series is characterized by deficits almost throughout the entire sample period. And, what's more, CA series suffers also from an unstable course where surpluses are followed by deficits repeatedly. Depending on this initial visual inspection, one can deduce that there may exist a statistically genuine comovement between the fiscal and external imbalances in Turkey. The empirical validity of a potential reciprocity between $\mathrm{BB}$ and $\mathrm{CA}$ series is explored in the following sections by formal econometric procedures.

\subsection{Empirical Methodology}

\subsubsection{Unit Root Testing}

Before making an analysis to examine the relationship between any two series, time series properties of those individual series should be determined by formal unit root tests. Stationarity is one of the most important issues in time series econometrics, since the 
regressions established with non-stationary series may lead to spurious, thus unreliable results. Yule (1926) is the first study which pointed out that pitfall long ago and labelled it as spurious regression, where one random walk process is regressed on another. The Rsquared and the coefficient estimates of the model are no more dependable since the tstatistic values are biased in case of a spurious relationship. Granger and Newbold (1974), Phillips (1986) and Durlauf and Phillips (1986) also tested formally for spurious regressions. This study performs the Augmented Dickey-Fuller (ADF) unit root test, introduced by Dickey and Fuller (1979), to check the integration order, namely the unit root structure of $\mathrm{CA}$ and $\mathrm{BB}$ series. ADF test tests the null of non-stationarity against the alternative of stationarity.

\subsubsection{Residual-Based Cointegration Analysis with a Fourier Series Approximation}

The cointegration method, initially developed by the trailblazing studies by Hendry (1986), Granger (1986), and Engle and Granger (1987), proposes modelling the stationary relationship among the two or more nonstationary data series while still keeping the valuable long-run information which otherwise might have been lost by first differencing the series. A long-run equilibrium relationship among the series evidences that these series are cointegrated, namely they possess a common trend. If two series prove to be cointegrated, then a finding that there is no causality [in terms of Granger's (1969) definition illustrated below] between these two series in either direction would never be the case, meaning that at least one unidirectional or bidirectional causality should exist. Moreover, as noted by Masih and Masih (1996), a cointegration among the data series guarantees that the relationship is not spurious, namely it is genuine. By taking advantage of these empirical suggestions, this study adopts both the cointegration and Granger causality analyses to ensure that the parameter estimates are robust.

A Fourier series approximation in a cointegration setting basically entails superimposing Fourier series components into the conventional, i.e. Engle and Granger's (1987), cointegration equation. This approach is initially developed by Tsong et al. (2016) and Banerjee et al. (2017). Following the earlier criticisms by Gregory and Hansen (1996) and Hatemi-J (2008), Y1lanc1 (2019) proposed a residual-based cointegration procedure where smooth structural breaks of indefinite number and form are approximated via a Fourier series component ${ }^{3}$. By so doing, Y1lanc1 (2019) allows for unspecified type of nonlinearities captured thanks to the trigonometric components embedded in the Fourier series. His testing methodology commences with estimating Eq. (1).

$$
y_{t}=d(t)+\beta^{\prime} X_{t}+\varepsilon_{t}
$$

3 Gregory and Hansen (1996) and Hatemi-J (2008) are the prominent papers which criticize the conventional Engle-Granger cointegration test for its lessened power due to the omission of structural changes. However, Gregory and Hansen (1996) and Hatemi-J (2008) have a shortcoming in common that the number, form, and exact point of the structural shifts are determined by presumption in their estimation framework. 
In Eq. (1), $t=1,2, \ldots, T . y_{t}$ is a scalar regressand, and $X_{t}=\left(x_{1 t}, x_{2 t}, \ldots, x_{n t}\right)^{\prime}$ is a vector of regressors with ( $n x 1)$ dimensions. $\varepsilon_{t}$ is the error term. The following equation, namely Eq. (2), represents a Fourier series with a single-frequency component. It is utilized to approximate $d(t)$, which is a deterministic function of $t$.

$$
d(t)=\delta_{0}+\gamma_{1} \sin \left(\frac{2 \pi k t}{T}\right)+\varphi_{1} \cos \left(\frac{2 \pi k t}{T}\right)
$$

In Eq. (2), $\delta_{0}$ stands for the deterministic component which has a constant with or without a linear trend; $T$ symbolizes the number of observations; and $k$ represents the optimal number of breaks, i.e. frequency, which minimizes the sum of squared residuals. $t$ is the time trend, and $\pi$ is identical to 3.1416. In order for the Fourier series approximation to be valid in a statistical sense, the parameter estimates for the trigonometric components, namely $\gamma_{1}$ and $\varphi_{1}$, should prove to be non-zero and at the same time the F-statistic value for Eq. (1) should imply significance. Otherwise, Fourier-type cointegration, or the Fourier Engle-Granger (FEG) setting would yield to the conventional (linear) Engle-Granger methodology. Eq. (3) is obtained by substituting Eq. (2) into Eq. (1).

$$
y_{t}=\delta_{0}+\gamma_{1} \sin \left(\frac{2 \pi k t}{T}\right)+\varphi_{1} \cos \left(\frac{2 \pi k t}{T}\right)+\beta^{\prime} X_{t}+\varepsilon_{t}
$$

The next step requires applying an ADF test to the residuals obtained from Eq. (3). This process is represented by Eq. (4) below. The null of no cointegration would be rejected if the residual series proves to display stationarity.

$$
\Delta \hat{\varepsilon}_{t}=\rho \hat{\varepsilon}_{t-1}+\sum_{i=1}^{p} \theta_{i} \Delta \hat{\varepsilon}_{t-i}+u_{t}
$$

In Eq. (4), $u_{t}$ is independently and identically distributed with zero mean and variance $\sigma^{2}$. The test statistic $\tau_{F E G}$ is calculated by Eq. (5).

$$
\tau_{F E G}=\frac{\widehat{\rho}}{\operatorname{se}(\widehat{\rho})}
$$

In the ratio shown in Eq. (5), $\hat{\rho}$ and $s e(\hat{\rho})$ stand for the ordinary least squares (OLS) estimate of $\rho$ and the standard error of $\hat{\rho}$, respectively.

\subsubsection{Granger Causality Tests}

\subsubsection{Conventional (Linear) Granger Causality Test}

Having demonstrated by unit root tests that the variables under examination are integrated of the same order, i.e. both series become stationary after first differencing [ $y_{t}$ and $X_{t} \sim I(1)$ ], one can continue with the causality testing initially suggested by Granger (1969). His testing routine, which depends on the simple logic that the two stationary and zero mean series, namely $y_{t}$ and $X_{t}$, are regressed on the lagged values of their own, is presented by $\mathrm{Eq}(6) . \varepsilon_{t}$ and $\eta_{t}$ represent uncorrelated white-noise disturbances. 


$$
\begin{aligned}
& X_{t}=\sum_{j=1}^{m} a_{j} X_{t-j}+\sum_{j=1}^{m} b_{j} y_{t-j}+\varepsilon_{t} \\
& y_{t}=\sum_{j=1}^{m} c_{j} X_{t-j}+\sum_{j=1}^{m} d_{j} y_{t-j}+\eta_{t}
\end{aligned}
$$

\subsubsection{Fourier Granger Causality Test}

Enders and Jones (2016) recommend utilizing a dummy in case of a non-smooth structural change in order to determine the right point of the break. On the other hand, if the break is smooth, one should follow a different stance. Enders and Jones (2016) employ Gallant's (1981) flexible Fourier series components illustrated by Eq. (7). Note that the idea behind Eq. (7) is identical to the one used to write Eq. (2). They superimpose Eq. (7) into the linear Granger causality setting, namely Eq. (6), to estimate the resulting Eq. (8).

$$
\begin{aligned}
& d(t)=a_{0}+a_{1} \sin \left(\frac{2 \pi k t}{T}\right)+b_{1} \cos \left(\frac{2 \pi k t}{T}\right) \\
& y_{t}=\beta_{0}+\beta_{1} \sin \left(\frac{2 \pi k t}{T}\right)+\beta_{2} \cos \left(\frac{2 \pi k t}{T}\right)+\sum_{i=1}^{p} \theta_{i} y_{t-i}+\sum_{i=1}^{p} \delta_{i} X_{t-i}+\varepsilon_{t}
\end{aligned}
$$

and

$$
X_{t}=\gamma_{0}+\gamma_{1} \sin \left(\frac{2 \pi k t}{T}\right)+\gamma_{2} \cos \left(\frac{2 \pi k t}{T}\right)+\sum_{i=1}^{p} \tau_{i} y_{t-i}+\sum_{i=1}^{p} \varphi_{i} X_{t-i}+u_{t}
$$

\section{Estimations and Their Inference}

Time series features of the variables $\mathrm{CA}$ and $\mathrm{BB}$ are explored by ADF unit root tests, the findings of which are shown in Table 2. According to the estimations depicted in Table 2 , the two balances are proved to be integrated of order one, meaning that they both have a unit root at the level. To put it another way, Table 2 evidences that the first differenced CA and $\mathrm{BB}$ series no longer have a unit root, namely they become stationary.

Table: 2

\section{ADF Unit Root Test Results}

\begin{tabular}{|c|c|c|}
\hline & \multicolumn{2}{|c|}{ ADF Test Statistic } \\
\hline Variables & Intercept & Intercept and Trend \\
\hline $\boldsymbol{C} \boldsymbol{B}$ & $-2.694665[8]$ & $-3.288606[8]$ \\
\hline $\boldsymbol{B}$ & $-2.177017[4]$ & $-2.118151[4]$ \\
\hline $\boldsymbol{C} \boldsymbol{A}$ & $-3.585675 \dagger \dagger[8]$ & $-3.498852 \dagger[8]$ \\
\hline $\boldsymbol{B} \boldsymbol{B}$ & $-11.17234 \dagger \dagger[2]$ & $-11.05453 \dagger \dagger[2]$ \\
\hline
\end{tabular}

Note: Symbols $\dagger$ and $\uparrow$ represent statistical significance at $1 \%$ and $5 \%$, respectively. Values in brackets show the lag length.

Having determined the unit root structures of the series, I proceeded by building the residual-based cointegration setting with a Fourier series component. Two models, namely Model I and Model II, are tested to empirically investigate the entire theoretical relationships between BB and CA, namely the TDH, REH, TDiH, and the CATH. More specifically, Model I, where CA is the dependent and BB is the independent variable, tests for the TDH, $\mathrm{REH}$, and the TDiH; whereas Model II, where the dependent and independent variables in 
Model I are interchanged, is constructed with the purpose to examine the CATH. The findings from the estimations for Model I and Model II are displayed below in Table 3.

The signs of the statistically significant coefficients for the regressors in the long-run models help to determine the hypothesis that should be singled out as empirically valid, having established that the findings from the FEG estimations (shown in Table 3) point to the existence of a long-run equilibrium under smooth breaks. More specifically, if the sign of the coefficient for BB in Model I proves to be positive, then the TDH turns out to be the case for the Turkish data. However, if the sign is found to be negative, then the TDiH would be empirically verified. Finally, in order for the REH to hold true, the parameter should turn out to be zero or statistically insignificant. As for Model II, to claim that the CATH is the case for Turkey, the significant parameter estimate for CA should have a positive sign. When the recurrent deficits both in the government budget and the current account are considered in a retrospective viewpoint, I expect that the sign of the estimated parameter for BB in Model I would be positive, certifying that the TDH is the framework picturing the Turkish data. Alternatively, a reversed relationship is likewise consistent with my expectations, as long as it is confirmed by a significant and positive coefficient estimate for CA in Model II, which implies the CATH.

Table: 3

Residual-Based Fourier Cointegration (FEG) Test Results

\begin{tabular}{|c|c|c|c|}
\hline Models & Frequency $(k)$ & SSR & Test statistic for the model \\
\hline Model I: $\boldsymbol{C} \boldsymbol{A}_{\boldsymbol{t}}=\boldsymbol{\delta}_{\mathbf{0}}+\boldsymbol{\delta}_{\mathbf{1}} \boldsymbol{B} \boldsymbol{B}_{\boldsymbol{t}}+\boldsymbol{\delta}_{\mathbf{2}} \sin \left(\frac{2 \pi k t}{T}\right)+\boldsymbol{\delta}_{\mathbf{3}} \cos \left(\frac{2 \pi k t}{T}\right)+\boldsymbol{\omega}_{\boldsymbol{t}}$ & 3 & 0.0344 & $-4.1147 \dagger[4]$ \\
\hline Model II: $\boldsymbol{B} \boldsymbol{B}_{\boldsymbol{t}}=\boldsymbol{a}_{\mathbf{0}}+\boldsymbol{a}_{\mathbf{1}} \boldsymbol{C} \boldsymbol{A}_{\boldsymbol{t}}+\boldsymbol{a}_{\mathbf{2}} \sin \left(\frac{2 \pi k t}{\boldsymbol{T}}\right)+\boldsymbol{a}_{\mathbf{3}} \cos \left(\frac{2 \pi k t}{T}\right)+\boldsymbol{u}_{\boldsymbol{t}}$ & 1 & 0.0256 & $-2.9577[5]$ \\
\hline
\end{tabular}

Note: Values in brackets represent the optimal lag length selected depending on the Schwarz Information Criterion. Symbols $\dagger$ and $\dagger+$ stand for statistical significance at $5 \%$ and $1 \%$, respectively. Critical values for $T=58, k=3$, and $n=1$ are -4.437 and -3.743 at $1 \%$ and $5 \%$ significance levels, respectively; whereas those for $T=58, k=1$, and $n=1$ are -4.906 and -4.302 at $1 \%$ and $5 \%$ significance levels, respectively.

As far as the findings reported in Table 3 are concerned, there appears to be a cointegration relationship in Model I, running from BB to CA. In spite of that, there is no evidence supporting the existence of a reversed cointegration illustrated by Model II. This means that the CATH is not empirically confirmed for Turkey. To sum up, these findings suggest that there exists a long-run equilibrium between $\mathrm{CA}$ and $\mathrm{BB}$, only when Model I is the case. The next step involves running the long-run as well as the cointegration, i.e. shortrun, equations for Model I. By so doing, the exact sign and magnitude of the long-run impact on $\mathrm{CA}$ of $\mathrm{BB}$ and the speed of adjustment to the long-run equilibrium are explored, which are disclosed in Table 4 and Table 5, respectively. 
Table: 4

\section{Long-Run Equation Estimation Results}

\begin{tabular}{|c|c|}
\hline Dependent variable: $\boldsymbol{C A}$ & Model I - Dynamic OLS estimator \\
\hline Independent variables & Coefficients \\
\hline $\boldsymbol{C}$ & $0.013922 \dagger \dagger \dagger(2.734751)$ \\
\hline $\boldsymbol{B B}$ & $0.403453 \dagger \dagger(2.035529)$ \\
\hline $\boldsymbol{\operatorname { s i n }}(\mathbf{2} \boldsymbol{k} \boldsymbol{t} / \boldsymbol{T})$ & $-0.021995 \dagger \dagger \dagger(-4.487472)$ \\
\hline $\boldsymbol{c o s}(\mathbf{2} \boldsymbol{k} \boldsymbol{t} / \boldsymbol{T})$ & $-0.009271 \dagger \dagger(-2.247643)$ \\
\hline $\boldsymbol{R}^{\mathbf{2}}$ & 0.377096 \\
\hline
\end{tabular}

Note: Values in parentheses represent $t$-statistics. Symbols $\dagger, \dagger$, and $\dagger+\dagger$ stand for statistical significance at $10 \%$, $5 \%$, and $1 \%$, respectively.

Table: 5

\section{Cointegration (Short-Run) Equation Estimation Results}

\begin{tabular}{|c|c|}
\hline Dependent variable: $\boldsymbol{\Delta C A}$ & Model I - Dynamic OLS estimator \\
\hline Independent variables & Coefficients \\
\hline $\boldsymbol{C}$ & $0.000019(0.007820)$ \\
\hline $\boldsymbol{B} \boldsymbol{B}$ & $0.782191 \dagger \dagger(2.638495)$ \\
\hline $\boldsymbol{E C T}$ & $-0.407898 \dagger \dagger(-2.163847)$ \\
\hline $\boldsymbol{R}^{2}$ & 0.449902 \\
\hline
\end{tabular}

Note: Values in parentheses represent $t$-statistics. Symbols $\%$ $\dagger$, and $\dagger \dagger \dagger$ stand for statistical significance at $10 \%$, $5 \%$, and $1 \%$, respectively.

Table 4 illustrates the long-run coefficient estimates for Model I by the dynamic OLS (DOLS) estimator ${ }^{4}$. The findings uncover that the TDH holds in Turkey with a significant and positive coefficient estimate for $\mathrm{BB}$, which amounts to 0.40 . The trigonometric components of the model are also statistically significant. The outcome from the short-run estimations (displayed in Table 5) unveils that the finding of a long-run equilibrium for Model I, which is established by the FEG test results, is acknowledged by the significant and negative coefficient estimate for the error correction term $(E C T)$, which is equal to 0.40. This value implies the percentage point by which the long-run disequilibrium in CA series is cleared each quarter. The ECT is a short-run adjustment parameter, but since it is extracted from the long-run equation as the lagged residuals, it comprises the long-run information. Though, the short-run parameter estimates for $\triangle B B$, which adds up to 0.78 , is as well statistically significant, the TDH, just like many other macroeconomic theories, does not put anything regarding the short term. In light of these findings, one can infer that a $1 \%$ rise in the fiscal balance brings about a $0.40 \%$ increase, namely an improvement, in the current account balance in Turkey. This implies that the reason behind the obstinate external imbalance is proved to be the equally stubborn fiscal deficits in Turkey.

Since, the findings revealed that there is a cointegration between $\mathrm{CA}$ and $\mathrm{BB}$ in Model I, there should also exist at least one causal relationship (in the Granger sense) between the two balances, which can either be unidirectional or bidirectional. For this

4 The DOLS estimator is originally suggested by Stock and Watson (1993). It is a parametric method that incorporates the lags and leads of the differenced independent variable(s) into the equations so as to overcome the problems of simultaneity and small sample bias. The methodology is quite similar to those developed by Phillips and Loretan (1991) and Saikkonen (1991), however it is easier to estimate and interpret compared to these two earlier procedures. 
reason, as stated above, Granger causality tests are performed for robustness check purposes. Both linear and Fourier-type causality tests are applied to the data set to compare the findings shown in Table 6.

Table: 6

Conventional and Fourier-Type Granger Causality Test Results

\begin{tabular}{|c|c|c|c|c|c|c|}
\hline \multicolumn{2}{|c|}{ Procedure } & Null & $\begin{array}{c}\text { Wald } \\
\text { Statistic }\end{array}$ & Probability & $\begin{array}{c}\text { Optimal } \\
\text { Lag Length }\end{array}$ & $\begin{array}{c}\text { Optimal Frequency } \\
\text { Number }(k)\end{array}$ \\
\hline \multirow{2}{*}{ Linear (conventional) } & Granger (1969) causality & $\Delta C A \neq>\Delta B B$ & 6.279 & 0.0988 & 3 & - \\
\cline { 3 - 7 } & & $\Delta B B \neq>\Delta C A$ & 15.384 & 0.0015 & 3 & - \\
\hline \multirow{3}{*}{$\begin{array}{c}\text { Nonlinear } \\
\text { (Enders \& Jones, 2016) }\end{array}$} & $\begin{array}{c}\text { Fourier Granger Causality } \\
\text { (Single Frequency) }\end{array}$ & $\Delta C A \neq>\Delta B B$ & 6.631 & 0.106 & 3 & 2 \\
\cline { 2 - 7 } & $\begin{array}{c}\text { Fourier Granger Causality } \\
\text { (Cumulative Frequency) }\end{array}$ & $\Delta B B \neq>\Delta C A$ & 14.771 & 0.005 & 3 & 2 \\
\cline { 3 - 7 } & & $\Delta B B \neq>\Delta B B$ & 4.756 & 0.214 & 3 & 3 \\
\hline
\end{tabular}

Note: Probability values for Fourier Granger causality tests are determined by 10000 bootstrap replications. $A \neq$ $>B$ represents the null of "A does not Granger cause B".

According to the findings shown in Table 6, there is a two-way causality between the $\mathrm{CA}$ and $\mathrm{BB}$ series, as far as the result of the linear Granger causality test is concerned. On the other hand, the findings from the Fourier Granger causality test unearth that there exists only a one-way causality running from the fiscal balance to the external balance under smooth structural breaks, a finding acknowledging that the two balances are twins. This finding parallels that from the FEG cointegration framework, which also supported the validity of the TDH in Turkey. The compromise between the findings from the FEG cointegration and Fourier causality tests evidence that robust parameters are obtained from the estimations. The justification for the disagreement between the findings from the linear and Fourier-type causality specifications is that the first approach is not designed to capture the nonlinearities caused by the structural changes in the data, whereas the latter test detects only the genuine causality under the existence of smooth structural changes.

\section{Conclusion and Policy Recommendations}

The academics have been bringing the association between the budget and the current account balances to the governments' attention, ever since the early 1980s when they detected that these balances suffer from deficits simultaneously. The leading researchers focused primarily on the US data, since the budget and the current account deficits were climbing concurrently then in the US, which led the scholars, and even the non-professionals to think that the two imbalances may be "twins".

There are certain approaches depicting the relationship between the fiscal and current account balances. The first approach, the twin deficit hypothesis (TDH), claims by relying on the Mundell-Fleming framework that the reason for the deepening current account deficit is the expanding budget deficit. The second hypothesis is the Ricardian equivalence hypothesis (REH), which puts forward that the link between the two balances is broken due to the existence of foresighted agents. Thirdly, the twin divergence hypothesis (TDiH) suggests that a growing budget deficit leads to an improvement in the current account, instead of a worsening. There is also a fourth hypothesis which illustrates a reversed 
relationship. According to this view, labelled the current account targeting hypothesis (CATH), an improving current account is the cause for a surplus in the government budget.

This study investigates the linkage between the Turkish budget and current account balances by utilizing quarterly data covering the period 2006:1 and 2020:2 and adopting residual-based Fourier cointegration and Fourier Granger causality techniques. This study is motivated by the fact that the empirical literature on the TDH and other theoretical settings is quite mixed even for similar countries or country groups or for overlapping data. There is a consensus in the literature that the reason for this ambiguity in the findings is that the empirical studies conducted thus far generally made light of the nonlinearities that the data may include. By following this criticism, the present study adopts cointegration and Granger causality procedures which are predicated on a flexible Fourier series approximation. More specifically, the residual-based Fourier cointegration (or FEG) and the Fourier causality approaches consider nonlinearities that stem from structural changes of unknown number and form thanks to their trigonometric components. That is, these techniques allow for nonlinearities without imposing any presumption on the exact shape, number, or point of the structural break(s). As far as the author is concerned, the novelty of the empirical findings from this paper can be attributed to the fact that there does not exist any previous study which employs residual-based cointegration and causality tests with flexible Fourier series components in the investigation of the TDH. This mixed methodology serves as a robustness check for the parameter estimates, which adds to reliability and originality of the findings.

The findings from the cointegration analysis suggest that a long-run equilibrium exists between the current account balance (CA) and the budget balance (BB) in the context of Model I, where the first is the dependent and the latter is the independent variable. Besides, no evidence is found in support of a reversed cointegration represented by Model II, verifying that the CATH does not hold true for the Turkish data. Depending on the cointegration relationship found in Model I, the long- and short-run versions of Model I are estimated by the DOLS estimator to explore respectively the precise sign and magnitude of the long-run effect of $\mathrm{BB}$ on $\mathrm{CA}$ and the speed of correction to establish the long-run equilibrium. According to these estimates, a $1 \%$ improvement in the fiscal balance gives rise also to a $0.40 \%$ amelioration in the current account balance in the long run. The parameter estimate for the error correction term in the short-run model is statistically significant and negative, a result that substantiates the cointegration between the two balances. In view of these pieces of empirical evidence, TDH turns out to be the theoretical justification for the coexistence of almost continually rising fiscal and current account deficits in Turkey, which is congruous with my prior expectations. Additionally, the findings from the Fourier-type causality tests support those from the FEG analysis. They revealed that there is a one-way causality running from $\mathrm{BB}$ to $\mathrm{CA}$ under smooth breaks, but not vice versa. This combined with the FEG test results demonstrates that the TDH is validated for Turkey. The compatible findings from two different Fourier-type methodologies proved that the parameter estimates are robust. 
The primary economic policy suggestion that follows from the findings is that restoring the fiscal discipline is an essential element for Turkey to cope with the chronic current account imbalances. More precisely, the Turkish policy makers should pay a greater attention to increasing the revenues and reducing the expenditures to bring the budget back into balance. This action indicates a major fiscal policy change which also requires a large government plan. Since the likely public reaction to a tight budget policy would be unpleasant from the policy makers' perspective, bringing such a policy into reality takes determination as well as a dramatic shift in the deep-rooted convention of "open-handed" fiscal practice.

\section{References}

Abell, J.D. (1990), "Twin deficits during the 1980s: An empirical investigation", Journal of Macroeconomics, 12(1), 81-96.

Ahmad, A.H. \& O.B. Aworinde \& C. Martin (2015), "Threshold cointegration and the short-run dynamics of twin deficit hypothesis in African countries", The Journal of Economic Asymmetries, 12, 80-91.

Algieri, B. (2013), “An empirical analysis of the nexus between external balance and government budget balance: The case of the GIIPS countries", Economic Systems, 37(2), 233-253.

Andersen, P.S. (1990), "Developments in external and internal balances: A selective and eclectic view", BIS Economic Papers, 29.

Anoruo, E. \& S. Ramchander (1998), "Current account and fiscal deficits: Evidence from five developing economies of Asia", Journal of Asian Economics, 9(3), 487-501.

Bachman, D.D. (1992), "Why is the US current account deficit so large? Evidence from vector autoregressions", Southern Economic Journal, 59, 232-240.

Bagnai, A. (2006), "Structural breaks and the twin deficits hypothesis", International Economics and Economic Policy, 3,137-155.

Banerjee, P. \& V. Arčabić \& H. Lee (2017), "Fourier ADL Cointegration Test to Approximate Smooth Breaks with New Evidence from Crude Oil Market", Economic Modelling, 67, 114-124.

Barro, R.J. (1974), “Are government bonds net wealth?”, Journal of Political Economy, 82(6), 10951117.

Barro, R.J. (1989), “The Ricardian approach to budget deficits”, The Journal of Economic Perspectives, 3(2), 37-54.

Baxter, M. \& M.J. Crucini (1993), "Explaining saving-investment correlations”, The American Economic Review, 83(3), 416-436.

Bilman, M.E. \& S. Karaoğlan (2020), "Does the twin deficit hypothesis hold in the OECD countries under different real interest rate regimes?", Journal of Policy Modeling, 42(1), 205-215.

Cavallo, M. (2005), "Government consumption expenditures and the current account", Federal Reserve Bank of San Francisco Working Paper Series, 2005-03.

Daly, V. \& J.U. Siddiki (2009), "The twin deficits in OECD countries: Cointegration analysis with regime shifts", Applied Economics Letters, 16(11), 1155-1164. 
Darrat, A.F. (1988), "Have large budget deficits caused rising trade deficits?", Southern Economic Journal, 54, 879-887.

Dewald, W.G. \& M. Ulan (1990), “The twin-deficit illusion”, CATO Journal, 9(3), 689-707.

Dickey, D.A. \& W.A. Fuller (1979), "Distribution of the estimators for autoregressive time series with a unit root", Journal of the American Statistical Association, 74(366a), 427-431.

Durlauf, S.N. \& P.C. Phillips (1986), "Multiple Time Series Regression with Integrated Processes", Review of Economic Studies, 53(4), 473-495.

Enders, W. \& B. Lee (1990), "Current account and budget deficits: Twins or distant cousins?", Review of Economics and Statistics, 72, 373-381.

Enders, W. \& P. Jones (2016), "Grain prices, oil prices, and multiple smooth breaks in a VAR", Studies in Nonlinear Dynamics \& Econometrics, 20(4), 399-419.

Engle, R.F. \& C.W. Granger (1987), "Co-integration and error correction: Representation, estimation, and testing", Econometrica, 55, 251-276.

Feldstein, M. \& C. Horioka (1980), "Domestic saving and international capital flows", The Economic Journal, 90(358), 314-329.

Feldstein, M. \& P. Bacchetta (1989), "National Saving and International Investment”, National Bureau of Economic Research Working Paper, 3164.

Feldstein, M. (1983), "Domestic Saving and International Capital Movement in the Long Run and the Short Run", European Economic Review, 21, 129-151.

Feldstein, M. (1992), “Analysis: The budget and trade deficits aren't really twins”, Challenge, 35(2), 60-63.

Frankel, J.A. \& A.T. MacArthur (1988), "Political vs. currency premia in international real interest differentials: A study of forward rates for 24 countries", European Economic Review, 32(5), 1083-1114.

Frankel, J.A. (1991), "Quantifying international capital mobility in the 1980s", in: National saving and economic performance, University of Chicago Press, 227-270.

Gallant, A.R. (1981), "On the Bias in Flexible Functional Forms and an Essentially Unbiased Form: The Fourier Flexible Form", Journal of Econometrics, 15(2), 211-245.

Gordon, R.J. (1986), "U.S. fiscal deficits and the world imbalance of payments", Hitotsubashi Journal of Economics, 27, 7-41.

Granger, C.W. (1969), "Investigating causal relations by econometric models and cross-spectral methods", Econometrica, 37(3), 424-438.

Granger, C.W.J. \& P. Newbold (1974), “Spurious regressions in econometrics”, Journal of Econometrics, 2(2), 111-120.

Granger, C.W.J. (1986), "Developments in the study of cointegrated economic variables", Oxford Bulletin of Economics and Statistics, 48, 213-228.

Gregory, A.W. \& B.E. Hansen (1996), "Residual-based tests for cointegration in models with regime shifts", Journal of Econometrics, 70(1), 99-126.

Hatemi-J, A. (2008), "Tests for cointegration with two unknown regime shifts with an application to financial market integration", Empirical Economics, 35(3), 497-505.

Helliwell, J.F. (1990), "Fiscal policy and the external deficit: Siblings, but not twins", NBER Working Paper Series, (3313), 1-26. 
Hendry, D.F. (1986), "Econometric modelling with cointegrated variables: An overview”, Oxford Bulletin of Economics and Statistics, 48(3), 201-212.

Holmes, M.J. (2011), "Threshold cointegration and the short-run dynamics of twin deficit behaviour", Research in Economics, 65(3), 271-277.

Kasa, K. (1994), "Finite horizons and the twin deficits", Economic Review, Federal Reserve Bank of San Francisco, 3, 19-28.

Kaufmann, S. \& J. Scharler \& G. Winckler (2002), “The Austrian current account deficit: Driven by twin deficits or by intertemporal expenditure allocation?", Empirical Economics, 27, 529-542.

Khalid, A.M. \& T.W. Guan (1999), "Causality tests of budget and current account deficits: Crosscountry comparisons”, Empirical Economics, 24(3), 389-402.

Kim, C.H. \& D. Kim (2006), “Does Korea have twin deficits?", Applied Economics Letters, 13(10), 675-680.

Kim, K.H. (1995), "On the long-run determinants of the US trade balance: A comment", Journal of Post Keynesian Economics, 17(3), 447-455.

Kim, S. \& N. Roubini (2008), "Twin deficit or twin divergence? Fiscal policy, current account, and real exchange rate in the U.S.”, Journal of International Economics, 74, 362-383.

Laney, L.O. (1984), "The strong dollar, the current account, and federal deficits: Cause and effect", Economic Review, Federal Reserve Bank of Dallas, 1-14.

Levy, D. (2000), "Investment-saving comovement and capital mobility: Evidence from century long US time series", Review of Economic Dynamics, 3(1), 100-136.

Marinheiro, C.F. (2008), "Ricardian equivalence, twin deficits, and the Feldstein-Horioka puzzle in Egypt", Journal of Policy Modeling, 30(6), 1041-1056.

Masih, R. \& A.M. Masih (1996), "Stock-Watson dynamic OLS (DOLS) and error-correction modelling approaches to estimating long- and short-run elasticities in a demand function: New evidence and methodological implications from an application to the demand for coal in mainland China”, Energy Economics, 18(4), 315-334.

McKinnon, R.I. (1980), “Exchange-Rate Instability, Trade Imbalances, and Monetary Policies in Japan and the United States", in: P. Oppenheimer (ed.), Issues in International Economics Ch. 12, Oriel Press, 225-250.

McKinnon, R.I. (1990), “The exchange rate and the trade balance”, Open Economies Review, 1(1), 17-37.

Miller, S.M. \& F.S. Russek (1989), “Are the twin deficits really related?”, Contemporary Economic Policy, 7(4), 91-115.

Murphy, R.G. (1984), “Capital Mobility and Relationship between Saving and Interest Rates in OECD Countries", Journal of International Money and Finance, 3, 327-342.

Normandin, M. (1999), "Budget deficit persistence and the twin deficits hypothesis", Journal of International Economics, 49(1), 171-193.

Obstfeld, M. \& K. Rogoff (2000), "Perspectives on OECD economic integration: Implications for US current account adjustment", in: Global Economic Integration: Opportunities and Challenges, 169-208.

Obstfeld, M. (1986), "How integrated are world capital markets? Some new tests", No. w2075, Working Paper, National Bureau of Economic Research. 
Phillips, P.C. \& M. Loretan (1991), "Estimating long-run economic equilibria”, The Review of Economic Studies, 58(3), 407-436.

Phillips, P.C. (1986), "Understanding Spurious Regressions in Econometrics”, Journal of Econometrics, 33(3), 311-340.

Piersanti, G. (2000), "Current account dynamics and expected future budget deficits: Some international evidence", Journal of International Money and Finance, 19(2), 255-271.

Rafiq, S. (2010), "Fiscal stance, the current account and the real exchange rate: Some empirical estimates from a time-varying framework", Structural Change and Economic Dynamics, 21, 276-290.

Saikkonen, P. (1991), “Asymptotically efficient estimation of cointegration regressions”, Econometric Theory, 7(1), 1-21.

Salvatore, D. (2006), "Twin deficits in the G-7 countries and global structural imbalances", Journal of Policy Modeling, 28, 701-712.

Stiglitz, J.E. (2010), Freefall: America, free markets, and the sinking of the world economy, WW Norton \& Company.

Stock, J.H. \& M.W. Watson (1993), “A simple estimator of cointegrating vectors in higher order integrated systems", Econometrica, 61(4), 783-820.

Summers, L.H. (1986), "Debt problems and macroeconomic policies”, NBER Working Paper Series, No. w2061.

Summers, L.H. (1988), "Tax policy and international competitiveness", in: International Aspects of Fiscal Policies, University of Chicago Press, 349-386.

Tobin, J. (1983), "Domestic Saving and International Capital Movements in the Long Run and the Short Run by M. Feldstein: Comment", European Economic Review, 21, 153-156.

Trachanas, E. \& C. Katrakilidis (2013), "The dynamic linkages of fiscal and current account deficits: New evidence from five highly indebted European countries accounting for regime shifts and asymmetries", Economic Modelling, 31, 502-510.

Tsong, C.C. et al. (2016), "The Fourier Approximation and Testing for the Null of Cointegration", Empirical Economics, 51(3), 1085-1113.

Vamvoukas, G.A. (1999), "The twin deficits phenomenon: Evidence from Greece”, Applied Economics, 31(9), 1093-1100.

Y1lanc1, V. (2019), “A Residual-Based Cointegration test with a Fourier Approximation”, MPRA Paper No. 95395.

Yule, G.U. (1926), "Why Do We Sometimes Get Nonsense Correlations between Time-Series? A Study in Sampling and the Nature of Time Series", Journal of the Royal Statistical Society, 89(1), 1-63.

Zietiz, J. \& D.K. Pemberton (1990), "The US budget and trade deficits: A simultaneous equation model”, Southern Economic Journal, 57, 23-34. 
Bilman, M.E. (2021), "Are Budget and Current Account Deficits Twins in Turkey? Evidence from Residual-based Fourier Cointegration and Fourier Causality Analyses”, Sosyoekonomi, 29(49), 199-215. 